\title{
Implikují vágní objekty vágní identitu? ${ }^{1}$
}

\author{
Petr Dvořák \\ Cyrilometodějská teologická fakulta \\ Univerzita Palackého v Olomouci \\ Univerzitní 244/22, 77111 Olomouc \\ petr.dvorak@upol.cz
}

\begin{abstract}
Článek z oblasti analytické metafyziky se věnuje problému, zda vágní objekty implikují vágní (neurčitou) identitu. Pokud by tomu tak bylo, pak lze s Evansem argumentovat tak, že vágní objekty nemohou existovat, protože vágní identita vede $\mathrm{k}$ nekoherenci. Studie představuje argument pro zmíněnou implikaci (Weathersonovský argument) a ukazuje, jak se jeho závěru vyhnout. Evansův argument předpokládá, že jména v tvrzeních o neurčité identitě referují určitě. Nejlepší cesta, jak se celému problému vyhnout, je tedy ukázat, že vágní objekty sice implikují vágní (neurčitou) identitu, ale v takových tvrzeních o identitě vystupují výrazy, které nereferují určitě. Tím vyřešíme i námitku, že sice tvrzení o identitě mezi vágním objektem a jeho přesnou realizací není neurčité, ale neurčité je tvrzení o identitě dvou vágních objektů.
\end{abstract}

Od devadesátých let dvacátého století stále více analytických metafyziků považuje za zdroj vágnosti nejen neurčenost významu či nedostatečnost našeho poznání, nýbrž i skutečnost samotnou. Podle těchto autorů existují tzv. vágní objekty, zpravidla objekty s neurčitými hranicemi v čase a prostoru, které lze definovat jako objekty, které mají některé své části či vlastnosti neurčitě. ${ }^{2}$ Již koncem sedmdesátých let však G. Evans v jednostránkovém článku formuloval argument, který ukazuje, že považovat

1 Článek je výstupem grantu spoluřešeného na CMTF UP „Neurčitá identita“ GAČR 17-12551S.

2 Srovnej např́lklad Bakerová (2007), Wilsonová (2013) pro koncepce určitě existujících vágních objektů s neurčitými hranicemi. Naproti tomu van Inwagen (1990) uznává za vágní objekty pouze ty, které vykazují vágní existenci a předchozí by za vágní objekty nepovažoval (jejich vágnost by redukoval na vágnost sémantickou). 
objekty za vágně či neurčitě identické není koherentní. ${ }^{3}$ Sám Evans se domníval, že nemožnost existence neurčité identity vyvrací i možnost existence vágních objektů jako takových, protože předpokládal, že vágní objekty implikují vágní identitu. ${ }^{4}$ Později byly formulovány argumenty, že tomu tak skutečně je. Nejznámější formulace pochází od B. Weathersona. ${ }^{5}$ Pokud tedy vágní objekty implikují vágní identitu a pokud platí Evansův argument, takové objekty nemohou existovat.

Naším cílem v tomto článku je prozkoumat druhý z argumentů, tj. ten, podle něhož vágní objekty implikují vágní identitu. Evansův argument a jeho předpoklady pouze představíme pro lepší pochopení celého problému. Jde nám o to zjistit, zda lze koherentně zastávat tuto pozici: na jednu stranu do naší ontologie přijímat vágní objekty, na druhou stranu neodmítat ani Evansův argument.

\section{Vágní objekty}

Představme si částici hmoty na okraji naší galaxie, ale již podstatně vzdálenou od těles, které jsou určitě její součástí. Je neurčité, zda daná částice do galaxie patř́ či nikoliv. Podobně lze uvažovat o elektronu v blízkosti povrchu stolu, či o částici na úpatí nějaké hory. Vezměme si slavnou africkou horu Kilimandžáro, kterou pro jednoduchost označíme výrazem

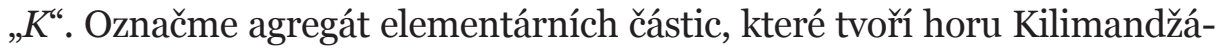
ro a zahrnují danou částici $S$ výrazem „ $K+$ “ a stejný agregát jen bez této částice „ $K$-“ $(K+$ a $K$ - sestávají z týchž částic až na $S)$. Zatímco „ $K$ “ referuje k vágnímu objektu - hoře Kilimandžáro, „,K+“ a „ $K$-“ referují k přesným agregátům částic. $K$ je vágní proto, že není určité, zda jej konstituuje či realizuje $K+$ nebo $K$-. $K$ má neurčitě část $S$, kterou má $K+$ určitě a $K$ - ji určitě nemá. Je zřejmé, že $K+$ a $K$ - jsou určitě odlišné. Naproti tomu se zdá, že $K$ a $K+$ či $K$ a $K$-nejsou určitě odlišné. Protože nejsou ani určitě totožné, lze říci, že jsou identické neurčitě. Neurčitá konstituce či realizace vágního objektu objekty přesnými by dávala vznik vágní, respektive neurčité identitě. Právě nastíněnou intuici do podoby argumentu převádí $\mathrm{B}$. Weatherson. Na něj přijde řada po představení již zmíněného Evansova argumentu.

3 Evans (1978).

4 Lewis (1988).

5 Weatherson (2003). Weatherson uvádí dva argumenty, jeden z nich je ve formální podobě (Weatherson uvádí neformálně) rozebrán níže v interpretaci Curtise \& Noonana (2014). 


\section{Evansův argument}

Evansův argument má tuto podobu. Abychom porozuměli zápisu, je třeba vědět, že „ $\nabla$ “ je operátor neurčitosti analogický modálnímu operátoru kontingence. ${ }^{6}$ Pomocí „, $\lambda x . .$. “, operace abstrakce, z predikace predikátu „F“ o $a$ ve výroku „Fa“ odvodíme predikaci vlastnosti, která je daným predikátem vyjádřena, „, $\lambda x[F x]$ “, o $a$, tedy , $\lambda x[F x] a^{“}$. Např́́klad z „Petr je člověk“ odvodíme „Petr má vlastnost lidstvi““.

$$
\begin{array}{ll}
\text { 1. } & \nabla(a=b) \\
\text { 2. } & \lambda x[\nabla(x=b)] a \\
\text { 3. } & \neg \nabla(b=b) \\
\text { 4. } & \neg \lambda x[\nabla(x=b)] b \\
\text { 5. } & \neg(a=b)
\end{array}
$$

V přirozeném jazyce:

1. je neurčité, že $a$ je totožné s $b$.

2. $\quad a$ má vlastnost být neurčitě identické s $b$.

3. není pravda, že je neurčité, že $b$ je totožné s $b$.

4. není pravda, že $b$ má vlastnost být neurčitě identické s $b$

5. není pravda, že $a$ je totožné s $b$.

Evansův argument je důkaz sporem. Z předpokladu, že $a$ a $b$ jsou neurčitě identické (1.) vyvodíme závěr o tom, že $a$ a $b$ jsou (určitě) navzájem různé (5.), což výchozímu předpokladu odporuje. Jsou-li totiž $a$ a $b$ neurčitě identické, znamená to, že nejsou určitě identické, a zároveň ani určitě různé. Vidíme, že poslední tvrzení je negací závěru. Závěr o tom, že $a$ a $b$ jsou různé, můžeme vyvodit podle kontraponovaného Leibnizova Principu Nerozlišitelnosti identických: má-li $a$ vlastnost, kterou $b$ nemá, pak jsou různé. Touto vlastností, kterou $a$ má (2.), ale $b$ nikoliv (4.), je vlastnost „být neurčitě identický s $b$ “.

Pokud tedy Evansův argument platí, idea neurčité identity není koherentní. Nic nemůže být s něčím neurčitě identické. Doplňme však, že

6 Modální operátor kontingence říká „v některých možných světech, ale v některých ne (tj. ne ve všech)“: $M p=_{d f} \diamond p \wedge \diamond \neg p$. 
Evansův argument popírá pouze neurčitou identitu objektů, které označujeme referenčně určitými výrazy. Pokud by alespoň jeden ze singulárních výrazů spojených symbolem identity $(a, b)$ byl z hlediska reference neurčitý, pak by takové tvrzení neurčité identity nebylo Evansovým argumentem vyloučeno. ${ }^{7}$ Vysvětleme proč. Tvrzení o identitě, v němž vystupuje takový neurčitě referující výraz, lze zpřesnit (precizovat) minimálně dvěma různými způsoby. Výraz s neurčitou referencí zpřesňujeme tím, že mu $\mathrm{v}$ různých precizacích (tedy alespoň ve dvou) přidělíme určitou referenci, v každé precizaci ovšem k jinému objektu. Pravdivostní hodnota tvrzení reflektuje pravdivostní hodnoty těchto tzv. precizací. Pokud se pravdivostní hodnoty $\mathrm{v}$ různých precizacích (v závislosti na přiděleném referentu) liší, jeden z přidělených objektů predikát splňuje a druhý ne, tvrzení nemá pravdivostní hodnotu, takže je pravda, že je neurčité. Pokud nyní provedeme abstrakční krok a o objektu, který je označen referenčně neurčitým výrazem, vypovídáme příslušnou vlastnost, získáme opět neurčitou, a nikoliv pravdivou predikaci, protože těchto objektů je více, v každé precizaci jiný, z nichž některý vlastnost má a jiný nikoliv. Odvození založené na abstrakčním kroku, od 1. premisy Evansova argumentu ke 2. a od 3. premisy ke 4., tedy neuchová pravdivost. $\mathrm{V}$ př́padě referenčně neurčitého výrazu vede od pravdivého tvrzení ke tvrzení bez pravdivostní hodnoty.

Pro lepší pochopení srovnej následující nesprávné odvození. Operátor kontingence je analogický operátoru neurčitosti. První znamená „V některých možných světech platí daný výrok a v některých ne“, druhý znamená „v některých precizacích platí daný výrok a v některých ne“:

1. Je nahodilé, zda je počet planet roven 8 .

2. Počet planet je takový, že je nahodilé, zda je roven 8 .

Určitá deskripce „Počet planet“ v 1. výroku referuje nerigidně. To znamená, že v každém možném světě referuje k jinému číslu (toto číslo se jistě svět od světa liší). Nerigidní reference určité deskripce je analogic-

7 Neurčitá reference a neurčitost objektu jsou dvě různé věci pro toho, kdo akceptuje existenci daných objektů. Ten, kdo popírá neurčitost objektů, ji redukuje na neurčitost reference (neurčitost reference $\mathrm{k}$ přesným objektům). K neurčitému objektu, existuje-li, lze referovat určitě či neurčitě. Právě vtip, jak se vyhnout Evansovu argumentu spočívá v tom, že se ukáže, že neurčitý objekt indukuje neurčitou referenci. 
ká neurčité referenci. Referenčně neurčitý výraz totiž v různých precizacích referuje k jiným objektům. Výrok „počet planet je roven 8“ tedy má v různých možných světech různou pravdivostní hodnotu. V některých je pravdivý, v některých nepravdivý. Proto je pravda, že je nahodilý.

Ve 2. tvrzení referuje určitá deskripce „počet planet“ k číslu 8, což je počet planet $\mathrm{v}$ aktuálním světě. Číslo 8 je v každém možném světě identické samo se sebou. Tedy 8 je nutně rovno 8 , nikoliv nahodile rovno 8. 2. tvrzení je tudíž nepravdivé, takže vyvození neuchová pravdivostní hodnotu, vede od pravdivého tvrzení k nepravdivému.

Protože se v Evansově argumentu abstrakční krok týká jednou vypovídání o $a$ a podruhé o $b$, je jasné, že stačí, aby bud' jméno „ $a$ “ nebo „ $b$ “ bylo referenčně neurčité, a argument bude obsahovat jeden neplatný inferenční krok. Aby byl tedy Evansův argument formálně správným vyvozením, musí být zaručeno, že „a“ a „ $b$ “ jsou referenčně určité výrazy.

\section{Weathersonův argument}

„K“, „K+“ a „K-“ jsou referenčně určité výrazy. Curtis a Noonan představují Weathersonův argument takto (operátor „D“ je představen níže): ${ }^{8}$

1. $\quad D(K=K+\leftrightarrow S$ je část $K)$

2. $\quad D(K=K-\leftrightarrow S$ není část $K)$

3. $\quad \nabla(S$ je část $K)$

4. $\quad \nabla(S$ není část $K)$

5. $\nabla(K=K+) \quad$ [z premis 1,3$]$

6. $\nabla(K=K-) \quad$ [z premis 2, 4]

8 Curtis \& Noonan (2014). Naproti tomu Barnesová \& Williams (2009) uvádějí argument v mírně odlišné podobě:

1. jestliže $S$ je část $K$, potom $K$ má stejné části jako $K+$

2. jestliže $S$ není část $K$, potom $K$ má stejné části jako $K$ -

3. Jestliže $K$ má stejné části jako $K+$, potom $K=K+$

4. Jestliže $K$ má stejné části jako $K$-, potom $K=K$ -

5. $S$ je část $K$ nebo $S$ není část $K$

6. $K=K+$ nebo $K=K$ - 
Vidíme, že se jedná o dva případy téže formy argumentu, první (premisy 1 , 3; závěr 5) a druhý (premisy 2, 4; závěr 6). Pro objasnění jejich platnosti tedy postačí vzít jen jeden z nich:

1. $\quad D(K=K+\leftrightarrow S$ je část $K)$

3. $\quad \nabla(S$ je část $K)$

5. $\nabla(K=K+)$

Nyní si uvědomme, že operátor „je neurčité, že“, symbolicky „ $\nabla^{\prime}$ “, s významem „v některých precizacích a v některých ne...“, je analogický operátoru nahodilosti „v některých možných světech a v některých ne...". Operátor „je určité, že“, symbolicky „D“, s významem „ve všech precizacích...“ je pak pochopitelně analogický operátoru nutnosti „ $\square$ “, „ve všech možných světech“.

Snadno nahlédneme, že je-li ekvivalence nějakých $p$ a $q$ nutná, tj. pravdivá $\mathrm{v}$ každém možném světě, a $q \mathrm{v}$ některých možných světech platí a v některých neplatí, pak v těch světech, kde platí $q$, bude platit i $p$, a v těch, v nichž neplatí $q$, neplatí ani $p$. Je tedy zřejmé, že $p$ má stejný charakter jako $q$, v některých světech platí, v některých neplatí. Je tedy také nahodilé. Totéž je jistě pravda, uvažujeme-li místo možných světů precizace a analogické operátory „, $D^{\prime \prime}$ a „, $\nabla^{\prime}$.

Zastánce platnosti Evansova argumentu, který do ontologie přijímá vágní objekty, má nyní dvě možnosti: možnost popřít alespoň jednu z premis argumentu nebo popřít, že by neurčitá identita (závěry 5. a 6.) spadala do pole působnosti Evansova argumentu. Druhé by bylo možné pouze tak, že by alespoň jeden z výrazů „, $K^{“}$ a „ $K++^{\text {“ }}$ nebyl referenčně určitým výrazem. $V$ příští sekci se dále budeme věnovat první strategii. ${ }^{9}$ V následující sekci se pak zaměříme na druhou cestu, kterou volí E. Barnesová a R. Williams.

\section{Různé strategie vyvrácení Weathersonova argumentu}

Je jasné, že zastánce vágních objektů nemůže popřít, že by vágní objekt $K$ měl danou část $S$ neurčitě nebo že by mu neurčitě chyběla, je-li $S$ (po-

9 Identitu mezi $K$ a $K+$, respektive $K$ - považuje za nepravdivou a nikoliv neurčitou např. Bakerová (2007) a Wilsonová (2013). 
dle předpokladu) ta část, o níž platí, že díky vztahu k ní je $K$ vágní objekt. Premisy 3. a 4. tedy „drží vodu“. Proto je třeba prozkoumat premisy 1. a 2.:

1. $D(K=K+\leftrightarrow S$ je část $K)$

2. $\quad D(K=K-\leftrightarrow S$ není část $K)$

Pokud by „, $K^{\prime \prime}$ referoval neurčitě, tj. k různým agregátům v různých preci-

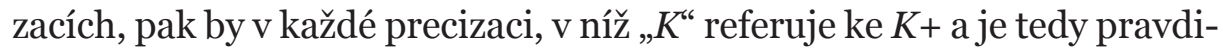
vá levá strana ekvivalence, byla pravdivá i její pravá strana $(S$ je skutečně část $K+$ ) a naopak..$^{10}$ My ale víme, že „ $K^{\prime \prime}$ referuje určitě.

Nabízí se popření první premisy. To může znamenat dvojí, bud’ že je ekvivalence $(K=K+\leftrightarrow S$ je část $K)$ nepravdivá (platí tedy $D \neg(K=K+$ $\leftrightarrow S$ je část $K)$ ), nebo že nemá pravdivostní hodnotu (pak platí $\nabla(K=$ $K+\leftrightarrow S$ je část $K$ )). Platí-li první, pak v každé precizaci nastává jedna z následujících možností: bud' $K=K+$ a $S$ není část $K$, nebo naopak $S$ je část $K$, ale není pravda, že $K=K+$. Platí-li druhé, pak v některé precizaci nastává jedna z následujících možností: bud' $K=K+$ a $S$ není část $K$, nebo naopak $S$ je část $K$, ale není pravda, že $K=K+$.

Uvažujme tuto druhou možnost a řekněme, že v některé precizaci je sice $S$ část $K$, tzn. $K$ a $K+$ koincidují, ale $K \neq K+$. V této precizaci neplatí ( $S$ je část $K \rightarrow K=K+$ ).

To by znamenalo, že neplatí Princip Identity nerozlišitelných pro části vztažený $k$ precizaci: ${ }^{11}$

Jestliže dva objekty $x$ a $y$ v libovolné precizaci $p$ koincidují ve všech svých částech, pak jsou $\mathrm{v} p$ identické.

Zastánce vágních objektů, který přijímá Evansův argument, tedy musí tento princip popřít. Pak je ekvivalence $(K=K+\leftrightarrow S$ je část $K)$ bez pravdivostní hodnoty a první premisa je tudíž nepravdivá. Argument tedy nemá pravdivé všechny premisy a není třeba přijmout jeho závěr.

10 Pak by byly pravdivé i zbývající premisy i závěr, nicméně by nešlo o neurčitou identitu, v níž oba singulární výrazy referují určitě, takže by zde nebyl problém s Evansovým argumentem.

11 Analogický princip pro modality je Princip Identity nerozlišitelných vztažený k možnému světu:

Jestliže dva objekty $x$ a $y$ v libovolném světě w koincidují ve všech svých částech, pak jsou ve $w$ identické. 
Zastánce vágních objektů tedy odmítá $D(S$ je část $K \rightarrow K=K+$ ), ale přijímá inferenci $S$ je část $K$, ergo $K=K+$, což odpovídá v supervaluační sémantice odmítnutí $D(p \rightarrow q)$, ale přijetí inference $p$, ergo $q .{ }^{12}$

Výsledkem právě řečeného je, že první premisa může mít jen podobu implikace $D(K=K+\rightarrow S$ je část $K)$, nikoliv ekvivalence. Zde se zdá, že náš zastánce Evanse a vágních objektů nemá problém s přijetím takové premisy, protože neurčitá identita $K=K+\mathrm{z}$ takto oslabené premisy neplyne. Přijme-li rozumné předpoklady, dá se odvodit, že je-li $K$ vágní objekt (mající neurčitou část, jak ř́ká druhá premisa), pak je identita $K=$ $K+$ nepravdivá:

Princip Nerozlišitelnosti identických pro části vztažený k možnému světu:

Jestliže jsou dva objekty $x$ a $y$ totožné v libovolném světě $w$, pak ve $w$ koincidují ve všech svých částech.

\section{Nutnost identity}

Jestliže jsou dva objekty $x$ a $y$ totožné $\mathrm{v}$ libovolném světě $w$, pak jsou totožné ve všech možných světech.

Z těchto dvou principů plyne Princip Nerozlišitelnosti identických pro části vztažený $k$ možným světům:

Jestliže jsou dva objekty $x$ a $y$ totožné v libovolném světě $w$, pak ve všech svých částech koincidují ve všech možných světech.

Analogické principy platí pro precizace. „Možný svět“ nahradíme výrazem „precizace“.

Vrat’me se nyní k našemu argumentu a jeho první premise. Ta ř́ká, že v každé precizaci, v níž jsou $K$ a $K+$ identické objekty, má $K$ část $S$. Má-li $K$ část $S$ v precizaci, pak koinciduje s $K+\mathrm{v}$ dané precizaci a naopak. Takže

12 Curtis \& Noonan (2014). 
jsou-li $K$ a $K+$ identické objekty v dané precizaci, pak podle Principu Nerozlišitelnosti identických v precizacích $K \mathrm{~s} K+$ koincidují ve všech precizacích. To znamená, že $S$ je část $K$ ve všech precizacích. To ale zajisté není pravda, protože $S$ je část $K$ jen v některých precizacích a $K \mathrm{~s} K+$ nekoincidují ve všech precizacích ( $K$ koinciduje s $K+$ jen v některých precizacích a v některých nikoliv).

Platí-li Princip Nerozlišitelnosti identických, platí

$D(K=K+\rightarrow S$ je část $K)$ implikuje $D(K=K+\rightarrow D(S$ je část $K)$ ).

Protože 3. premisa argumentu tvrdí, že $\nabla$ ( $S$ je část $K)$, pak platí $\neg D(S$ je část $K)$, takže i $\neg(K=K+)$ (modus tollens). Je-li $K$ vágní objekt s neurčitou částí $S$, potom je určitě odlišný od $K+$, které má část $S$ určitě.

Vrátí se nám problém, že z existence neurčitých objektů lze vyvodit neurčitou identitu, přijmeme-li obrácený princip, Princip Identity nerozlišitelných pro části vztažený k možným světům? Na první pohled by to tak snad mohlo vypadat. Princip zní takto:

Pokud dva objekty $x$ a $y$ koincidují ve všech svých částech ve všech možných světech, pak jsou v každém možném světě totožné. ${ }^{13}$

Vztažen na precizace tento princip spolu s Principem Nerozlišitelnosti identických umožňuje vyvodit tuto podobu první premisy: $D(D(K=K+)$ $\rightarrow D(S$ je část $K)):$

1. $D(K=K+\rightarrow D(S$ je část $K))$ na základě Principu Nerozlišitelnosti identických (viz výše)

13 Vztažen na precizace, princip zní $D(D(S$ je část $K) \rightarrow \mathrm{D}(K=K+))$. Pozor, z principu neplyne Princip Identity nerozlišitelných pro části vztažený k precizaci, který jsme odmítli výše a který by měl tuto podobu: $D$ ( $S$ je část $K \rightarrow K=K+$ ). Druhý není pravdivý, pokud existuje precizace p, v níž platí koincidence, ale nikoliv identita. Řekněme, že koincidence neplatí ve všech precizacích stejně jako identita. Pak je jasné (na základě modální logiky $\mathrm{S}_{5}$, jíž se řídí „D“), že první princip platí v každé precizaci, protože jeho antecedent i konsekvent jsou nepravdivé, ale implikace jako taková je pravdivá. 
2. $D(D(S$ je část $K) \rightarrow D(K=K+))$ Princip Identity nerozlišitelných

\section{vyvodíme}

$D(D(K=K+) \rightarrow D(S \text { je část } K))^{14}$

Druhá premisa argumentu, $\nabla(S$ je část $K)$, z níž plyne $\neg D(S$ je část $K$ ), popírá konsekvent poslední z implikací výše, tj. popírá $D$ ( $S$ je část $K)$, z čehož plyne (modus tollens) negace antecedentu dané implikace: $\neg D(K=K+)$, tedy ne-určitost identity $K$ a $K+{ }^{15}$ Tento závěr sám o sobě neodporuje přijetí Evansova argumentu, protože nevylučuje, že platí $D \neg(K=K+)$. Zastánce vágních objektů i Evansova argumentu tak nemusí popřít modální Princip Identity nerozlišitelných, resp. jeho aplikaci na precizace.

\section{5 . „K+ “ a „K-“ jsou referenčně neurčité}

Barnesová a Williams uvažují takto: ${ }^{16}$ Kromě Kilimandžára $K$ mějme ještě k němu duální objekt $K^{*}$. Oba se shodují v tom, že je neurčité, zda mají $S$. Ovšem dále platí, že má-li první z nich $S$, druhý $S$ nemá, a naopak. Jsou tedy možné dvě precizace: $P 1$ : první objekt má $S$, druhý nikoliv; $P 2$ : první nemá $S$, druhý ji má. Objekty jsou určitě různé, protože se liší vlastností

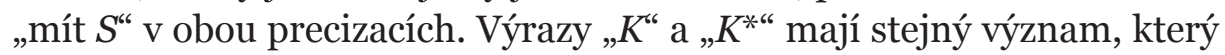
lze explikovat pomocí neurčité deskripce (indefinite description) ,jeden ze dvou duálních objektů, pro které platí, že má-li jeden část $S$, druhý ji nemá, a naopak“. ${ }^{17}$ Neurčitá je i reference výrazů „K+“ a „K-“. První

14 Toto vyvození je správné, závěr nemůže být nepravdivý, jsou-li premisy pravdivé: Závěr je nepravdivý, právě když existuje precizace, v níž není pravdivá implikace, tj. v níž uvedená identita platí ve všech precizacích, ale alespoň v jedné precizaci neplatí daná koincidence. Tato neplatnost koincidence v alespoň jedné precizaci ovšem nevadí z hlediska pravdivosti druhé premisy, protože nepravdivý antecedent znamená pravdivou implikaci. První premisa tak má nepravdivý konsekvent, nicméně antecedent musí být pravdivý, protože bylo řečeno, že identita platí ve všech precizacích. Takže v dané precizaci je implikace první premisy nepravdivá, a tím pádem je nepravdivá i první premisa jako taková, protože ř́ká, že daná implikace platí ve všech precizacích.

15 Ne-určitost, $\neg D$, není ještě neurčitostí, $\nabla$.

16 Barnesová \& Williams (2009).

17 Reference těchto výrazů je neurčitá, ale je neurčitá v jiném smyslu, než neurčitost výrazů „K+“ a „K“, o níž bude řeč dále. První typ neurčitosti vychází z toho, že objekty mohou být numericky 
je zkratkou za určitou deskripci „ten z duálních objektů, který má část

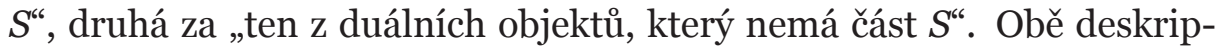
ce v jedné precizaci referují ke $K$, ve druhé ke $K^{*}$ : v $P 1$ „ $K+$ “ referuje ke $K$ a,$K$-“ ke $K^{*}$. V P2 je tomu naopak.

Klíčové je, co se tímto dosáhne. Ve vztahu $\mathrm{k}$ výrokům o identitě „K $K=K+{ }^{“}$ a,$K=K{ }^{-}$“ bude minimálně jeden inferenční krok Evansova argumentu neplatný. Omezme se jen na , $K=K+$ “. V $P 1$ bude pravdivý a v $P 2$ nikoliv, je tedy neurčitý a je pravda, že $\nabla(K=K+)$. Aplikujme abstrakční krok. Výrok „ $\lambda x[\nabla(K=x)] K+{ }^{\prime \prime}$ pravdivý nebude: v $P 1$ bude nepravdivý (, $K+$ “ referuje ke $K, K$ ani v jedné precizaci nemá vlastnost být neurčitě identické s $K$ ), v $P 2$ bude také nepravdivý („K+“ referuje ke $K^{*}$, přičemž „, $K^{\prime}$ referuje v každé precizaci k objektu, který má opačnou vlastnost než má objekt $K^{*}$, takže v každé precizace jsou určitě rozdílní), takže celkově je daný abstrakční výrok nepravdivý. Evansův argument tedy obsahuje krok od pravdivého výroku k nepravdivému, a tím pádem není platný.

\section{Námitka: neurčitost identity dvou vágních objektů}

Nejvyšší hora Rakouska, Grossglockner, je součástí dvojhory, tj. hory se dvěma vrcholy, přičemž Grossglockner je vyšším z těchto vrcholů a o něco nižší Kleinglockner je druhým vrcholem. Naproti tomu nejvyšší hora Evropy, Elbrus, je jedinou horou se dvěma vrcholy. Jak hluboké musí být údolí mezi dvěma vrcholy, aby se jednalo o dvě různé hory a nikoliv o dva vrcholy hory jediné? Lze tedy snadno myslet situaci, v níž dva vrcholy představují vrcholy dvou neurčitě identických hor. Zatímco dosud jsme pojednávali o neurčité identitě mezi vágním objektem a přesným objektem, který ho spolukonstituuje, nyní jde o neurčitou identitu mezi dvěma vágními objekty. Nazvěme si horu s jedním vrcholem $a$ a horu s druhým vrcholem $b$. Obě jsou vágními objekty, protože mají vágní části. Nazvěme si část, kterou má určitě hora $a$, ale hora $b$ ji má neurčitě, Č1; Č2 pak bude část, kterou obě hory sdílí a mají ji určitě; konečně Č 3 bude část, kterou má určitě hora $b$, ale hora $a$ ji má neurčitě. Je zřejmé, že je neurčité, zda $a=b$, přičemž „a“ a „b“ referují určitě.

odlišné, ale nemusí být určeno, který je který. Partikulární identita je tedy více než numerická odlišnost. Tyto objekty nelze zachytit určitou deskripcí, která předpokládá jedinečnost vlastnosti a tím partikulární identitu. 
Kromě takového synchronního př́íkladu vágní identity lze koncipovat i mnohé př́iklady neurčité diachronní identity: např́iklad známý myšlenkový experiment P. van Inwagena zvaný Skř́ň (the Cabinet). ${ }^{18}$ Osoba $a$ vejde do skříně, v níž je zařízení, které způsobí, že není určité, zda je po jistou dobu osoba naživu či ne. Ze zařízení po čase vystoupí osoba $b$. Není určité, zda $b$ je táž osoba jako $a$. A opět, „a“ a „b“ referují určitě.

Přijmeme-li existenci vágních objektů v čase a prostoru, u každého takového objektu lze myslet situaci či kontext (v nějakém možném světě), v němž implikuje podobné tvrzení o neurčité identitě, které podléhá Evansově redukci.

Jaké má tato obtíž řešení? Tyto př́iklady lze pojmout tak, že vždy jeden z výrazů ve tvrzení o identitě bude referovat neurčitě. Na taková tvrzení se nevztahuje závěr, jenž plyne z Evansova argumentu, o tom, že tvrzení o neurčité identitě jsou nekoherentní. Například „b“ bude zkratka za určitou deskripci: „ $a=b^{\prime}$ “je pak ekvivalentní tvrzení „a = hora s vrcholkem se souřadnicemi $\check{s} d$ “. Určitá deskripce „hora s vrcholkem se souřadnicemi šd“ v jedné precizaci referuje k $a$, ve druhé k jiné hoře, která určitě nemá část Č1. Stejně tak „b“ v diachronním příkladu znamená „ta jediná osoba, která vyšla ze zařízení“. Tato určitá deskripce jednou referuje k osobě $a$, podruhé k jiné osobě, která vznikla z osoby $a$ ve skřriňovém zařízení.

Jak ukázal Akiba, tato strategie nefunguje: ${ }^{19}$ Jako deskripci lze pojmout jméno „a“ i „b“, přičemž druhý z výrazů referuje určitě:

„a= hora s vrcholkem se souřadnicemi $\check{\mathrm{s}}_{1} d_{1}$ “

„hora s vrcholkem se souřadnicemi $\check{\mathrm{s}}_{2} d_{2}=b^{“}$

Tyto výroky implikují výrok „ $a=$ b“, kde „a“ a „b“ referují určitě. Na toto tvrzení se vztahuje Evansův argument.

Řešením je strategie, kterou jsme viděli u E. Barnesové a R. Williamse: ${ }^{20}$ Kromě hory $b$ existuje vůči ní duální hora $b^{*}$. Pro $b$ a $b^{*}$ platí, že má-li $b$ část $\check{C} 1, b^{*}$ tuto část nemá a naopak. Výrazy „b“ a „b*“ jsou tedy

18 van Inwagen (1990, s. 241n).

19 Akiba (2015).

20 Takové řešení naznačuje také Abasnezhad (2016). 
neurčité z hlediska reference (mají stejný význam a jejich významem je neurčitá deskripce). Tvrzení o identitě „ $a=b^{\prime}$ je pak neurčité, ale díky tomu, že „b“ referuje neurčitě, nevztahuje se na něj Evansův argument.

\section{Závěr}

Zastánce vágních objektů a zároveň platnosti Evansova argumentu má možnost popř́t, že by takové objekty nutně vedly k tvrzením o neurčité identitě s referenčně určitými výrazy. Weathersonovský argument o tom, že vágní objekty implikují taková tvrzení, lze odmítnout dvěma způsoby. První způsob vede $\mathrm{k}$ tomu, že jsou taková tvrzení o identitě (s referenčně určitými jmény) nepravdivá, nikoliv neurčitá. Druhý způsob ukazuje, že identita mezi vágním objektem a přesným agregátem, který jej neurčitě konstituuje, je sice neurčitá, ale tvrzení o identitě obsahuje alespoň jeden singulární výraz, který referuje neurčitě, takže se na něj nevztahuje závěr Evansova argumentu o nekoherenci tvrzení o neurčité identitě. Námitka, že identita mezi dvěma vágními objekty označenými referenčně určitými výrazy je neurčitá, a že se tedy problém s Evansovým argumentem vrací u výroků o identitě těchto objektů, je řešitelná shodně s druhým způsobem výše.

\section{Literatura}

Abasnezhad, A. (2016): „How (Not) To Argue Against Vague Object.“ Metaphysica 17 (2): 195-205. DOI: https://doi.org/10.1515/mp2016-0015.

Akiba, K. (2015): „How Barnes and Williams have failed to present an intelligible ontic theory of vagueness." Analysis 75 (4): 565-573. DOI: 10.1093/analys/anv074

Baker, L. R. (2007): The Metaphysics of Everyday Life: An Essay in Practical Realism. Cambridge University Press, Cambridge.

Curtis, B. L. \& Noonan, H. W. (2014): „Castles Built on Clouds: Vague Identity and Vague Objects." In Vague Objects and Vague Identity: New Essays on Ontic Vagueness, eds. K. Akiba \& A. Abasnezhad, Springer, Dordrecht, 2014, kap. 15, s. 305-326. 
Evans, G. (1978): „Can There Be Vague Objects?“ Analysis 38 (4): 208. DOI: $10.2307 / 3327996$.

van Inwagen, P. (1990): Material Beings. Cornell University Press, Ithaca.

Lewis, D. (1988): „Vague Identity: Evans Misunderstood.“ Analysis 48 (3): 128-130. DOI: 10.2307/3328214.

Williams, J. R. G. \& Barnes, E. (2009): „Vague Parts and Vague Identity." Pacific Philosophical Quarterly 90 (2): 176-187. DOI: https://doi.org/10.1111/j.1468-0114.2009.01335.x.

Weatherson, B. (2003): „Many Many Problems.“ The Philosophical Quarterly 53 (213): 481-501. DOI: https://doi.org/10.1111/14679213.00327.

Wilson, J. (2013): „A Determinable-based Account of Metaphysical Indeterminacy." Inquiry: An Interdisciplinary Journal of Philosophy 56 (4): 359-385. DOI: https://doi.org/10.1080/002017 4X.2013.816251.

\begin{abstract}
Do vague objects imply vague identity?

The paper in the field of analytic metaphysics focuses on a problem whether vague objects imply vague (indeterminate) identity. If this be so, one can argue with Evans that such objects cannot exist because vague identity leads to incoherence. The study presents an argument for such an implication (Weathersonian argument) and shows how to evade its conclusion. Evans' argument presupposes that names in indeterminate identity claims refer determinately. Hence the best way to evade the problem as a whole is to show that vague objects do imply vague (indeterminate) identity, but in such statements of identity, there appear expressions not referring determinately. By this we also solve the objection that the assertion of identity between a vague object and its precise realization is not indeterminate, but what is indeterminate is the identity statement concerning two vague objects.
\end{abstract}

Dvořák, P. (2018): „Implikují vágní objekty vágní identitu?“ Fỉlosofie dnes 10(1): 31-44. Dostupné z www.filosofiednes.ff.uhk.cz 